\title{
Penerapan Model Pembelajaran Children Learning in Science (CLiS) Upaya Meningkatkan Prestasi Belajar IPA
}

\author{
Ni Ketut Karsini ${ }^{1 *}$ iD \\ ${ }^{1}$ SD Negeri 1 Ubud, Gianyar, Indonesia \\ *Corresponding author: nikttkarsini45@gmail.com
}

\begin{abstract}
Abstrak
Tujuan dari penelitian ini adalah untuk mengkaji efektivitas model pembelajaran children learning in science untuk meningkatkan presatsi siswa. Siswa yang berlajar di kelas III A, pada Semester II, dijadikan objek penelitian yang bertujuan untuk mencapai peningkatan prestasi belajar IPA. Data yang diupayakan untuk diperoleh dikumpulkan dengan tes hasil belajar. Setelah diperoleh data, lalu dilakukan analisis menggunakan analisis deskriptif. Setelah pelaksanaan tindakan, data yang penulis dapatkan menunjukkan peningkatan yang baik, dari awalnya baru mencapai rata-rata 60,67, pada siklus I meningkat menjadi 64,86 dan pada siklus II meningkat menjadi 76,08. Dengan perolehan peningkatan hasil tersebut dapat disampaikan bahwa dengan menerapkan Model Pembelajaran Children Learning in Science (CLiS) dapat meningkatkan prestasi belajar IPA siswa.
\end{abstract}

Keywords: Children Learning in Science (CLiS), Prestasi Belajar Siswa

\section{Abstract}

The purpose of this study was to examine the learning model effectiveness of children learning in science to increase students' achievement. Students of grade III A, in semester II, are considered as research objects which aim to achieve an increase in science learning achievement. The data that was attempted to be obtained were collected by means of a learning outcome test. The data obtained then was analyzed using descriptive analysis. After the implementation of the action, the data showed a good increase, from the beginning which only reached an average of 60.67, in the first cycle increased to 64.86 and in the second cycle increased to 76.08. By obtaining an increase in these results, it can be said that implementing the Children Learning in Science (CLiS) Learning Model can improve students' science learning achievement.

Keywords: Children Learning In Science (CLiS) Learning Model, student learning achievement

\section{Introduction}

IPA adalah salah satu mata pembalajaran yang terdiri atas beberapa mata pelajaran seperti Kimia, Biologi, dan Fisika, yang di kombinasi sedimikain rupa, sehingga menjadi satu kesatuan. Pelajaran IPA adalah salah satu mata pelajaran yang penting karena dengan mempelajarai IPA siswa mampu mengetahui gejala-gejala atau fakta yang terjadi di alam (Panjaitan, 2017). Dengan adanya pembelajaran IPA maka siswa akan mampu memecahkan masalah yang ditemui dalam kehidupan sehari-hari (Yanti, 2017). Untuk mengujudkan hal tersebut maka dibutuhkan sebuah proses pembelajaran yang mampu mengembangkan kemampuan siswa baik pengetahuan, keterampilan maupun sikap. Pelajaran IPA adalah mata pelajaran terdiri dari konsep-konsep/materi padat yang memerlukan pemahaman yang luas, oleh sebab itulah proses pembelajaran ini membutuhkan inovasi dari guru dalam mengemasnya sehingga proses pembelajaran yang dihasilkan tidak membosankan.

$\begin{array}{lll}\text { History: } & \text { Publisher: Undiksha Press } \\ \text { Received }: 4 \text { Mei } 2020 & \text { Licensed: This work is licensed under } \\ \text { Revised } \quad \text { : Juni } 2020 & \text { a Creative Commons Attribution 3.0 License } \\ \text { Accepted : 6 Juli } 2020 & \\ \text { Published : } 30 \text { Juli } 2020 & \end{array}$


Namun, kenyataannya sangat berbeda dengan yang terjadi di lapangan, IPA menjadi salah satu pelajaran yang tidak diminati oleh siswa karena dianggap sangat membosankan dan sulit dipahami. Hal ini dapat dilihat dari hasil prestasi belajar siswa kurang memuaskan. Berdasarkan, hasil pengamatan guru kelas menyatakannya bahwa hasil belajar IPA yang dicapai siswa masih rendah. Masih banyak siswa yang mendapat nilai IPA di bawah KKM. KKM untuk mata pelajaran IPA, sendiri adalah 65. Ada 22 (sekitar 59,45\%) siswa masih belum mencapai nilai yang telah ditetapkan (KKM), sedangkan sisanya, 15 siswa (sekitar 40,54\%) telah mencapai KKM yang ditetapkan. Guru mengajar lebih mementingkan target yang berorientasi pada nilai dan terselesaikan nya materi. Di samping itu, metode yang digunakan masih metode konvensional, yaitu metode ceramah. Jika hanya menggunakan metode ceramah saja, peningkatan hasil belajar akan sulit dicapai karena kebosanan siswa. metode ceramah adalah metode yang mudah diterapkan dan dalam pembelajaran selalu membutuhkan ceramah, tetapi pada titik tertentu metode ini membosankan sehingga siswa tidak memperhatikan penjelasan guru, yang mengakibatkan siswa tidak memahami apa materi yang disampaikan. Disamping itu guru belum menggunakan metode pembelajaran.

Sebagai upaya meningkatkan hasil belajar siswa dalam pembelajaran IPA diterapkan Model Pembelajaran Children's Learning in Science (CLiS). Tindakan tersebut dikembangkan berdasarkan akar penyebab masalah. Model Pembelajaran Children's Learning in Science (CLiS) merupakan model pembelajaran yang berusaha mengembangkan ide atau gagasan siswa tentang suatu masalah tertentu dalam pembelajaran serta mengontraksikan ide atau gagasan berdasarkan hasil pengamatan atau percobaan. Pernyataan ini didukung oleh Ismail (2018) menjelaskan model pembelajaran Children Learning in Science (CLiS) adalah kerangka berpikir untuk menciptakan lingkungan yang memungkinkan terjadinya kegiatan belajar mengajar yang melibatkan siswa dalam kegiatan pengamatan dan percobaan dengan menggunakan LKS (Ismail, 2018). Rahayu dalam Arisantiani et al.,(2017); Rate Rusmala Sari, Indrawati, (2015) menyatakan bahwa model CLiS adalah salah satu model yang mengembangkan ide siswa dalam memecahkan masalah melalui proses percobaan. Model pembelajaran CLiS ini bertujuan untuk membentuk pengetahuan (konsep) ke dalam ingatan siswa agar konsep tersebut dapat bertahan lama, karena model pembelajaran CLiS memuat sederetan tahap-tahap kegiatan siswa dalam mempelajari konsep yang diajarkan. Dengan adanya model ini siswa akan lebih aktif karena sintak model pembelajaran ini lebih menekankan terhadap bagaimana cara siswa memecahkan masalah yang diberikan melalui percobaan.

Keaktifan siswa dalam proses pembelajaran akan berdampak terhadap hasil belajar siswa tersebut. Pernyataan ini didukung oleh Febrianto, (2016); Suarni, (2017); Zaeni \& Hidayah, (2002) yang menyatakan bahwa peningkatan keaktifan siswa berdampak juga terhadap peningkatan hasil belajar. Dengan penerapan model CLiS ini akan membuat suasananya belajar lebih menyenangkan sehingga hal ini berpengaruh terhadap hasil belajar siswa. pernyataan ini sesuai dengan hasil penelitian yang sudah dilakukan.

Penelitian yang dilakukan oleh Pratama, (2017) yang menyatakan bahwa terdapat pengaruh penggunaan model pembelajaran IPA dengan tipe CLiS meningkat terhadap hasil belajar. Ini dapat dilihat dari hasil penelitian yang dilakukan Nilai sig menyatakan $<0,01$, dan hasil pengujian dengan uji t post-test kelompok eksperimen dan kontrol -1,729 dan sig 0,097 nilai sig > 0, 01. Kusuma Wardani et al., (2017) menyatakan bahwa hasil penelitian menunjukkan nilai thitung lebih besar dari ttabel=2,340>1,68385 sehingga H0 ditolak dan H1 diterima dan nilai rata-rata post-test kelas eksperimen 82,36 lebih besar dari kelas kontrol 74,20. Dapat disimpulkan bahwa ada efektivitas model pembelajaran CLiS perbantuan media slide PowerPoint terhadap hasil belajar IPA siswa kelas V SDN Pulerejo Kecamatan Pilangkenceng Kabupaten Madiun Tahun Pelajaran 2016/2017. Ismail (2018) menyatakan bahwa keterampilan proses sains setelah diterapkan model pembelajaran Children Learning 
in Science (CLiS) perbantuan multimedia meningkat secara signifikan dilihat dari nilai gainnya. Berdasarkan hasil analisis data diperoleh rata-rata $\mathrm{N}$-gain keterampilan proses sains 57\% untuk kelas eksperimen dan $49 \%$ untuk kelas kontrol, Dapat disimpulkan bahwa model pembelajaran Children Learning in Science (CLiS) perbantuan multimedia dapat lebih meningkatkan keterampilan proses sains di bandingkan dengan pembelajaran konvensional perbantuan multimedia. Jadi, dapat dikatakan bahwa model CLiS berdampak positif terhadap hasil belajar. Sehingga dirumuskan sebuah tujuan penelitian yaitu untuk mengkaji efektivitas model pembelajaran children learning ini science untuk meningkatkan prestasi siswa.

\section{Materials and Methods}

Penelitian yang dilakukan termasuk penelitian tindakan. Oleh karenanya, rancangan yang khusus untuk sebuah penelitian tindakan sangat diperlukan. Berdasarkan sudut pandang pencapaian tujuan penelitian, rancangan penelitian berfungsi sebagai pedoman kerja (peta pedoman pengarahan bagi pelaksanaan penelitian). Fungsi lain, rancangan penelitian adalah sebagai rambu-rambu penentuan atau tolok ukur keberhasilan penelitian yang akan dilaksanakan. Memberikan petunjuk mengenai ukuran-ukuran sampai dimana penelitian yang dilakukan itu dikatakan mencapai hasil yang diinginkan.

Untuk penelitian ini penulis memilih rancangan penelitian tindakan yang disampaikan oleh Arikunto (2015) seperti terlihat pada Gambar 1.

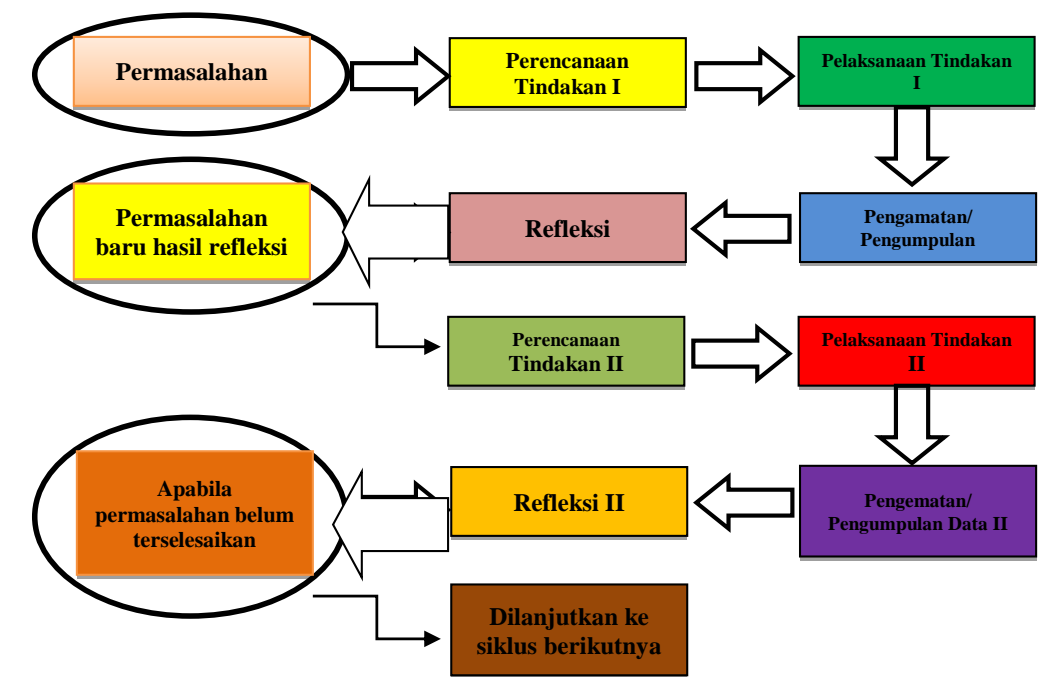

\section{Gambar 1. Alur Penelitian Tindakan Kelas}

Pertama, pada tahap ini peneliti membuat RPP, berkonsultasi dengan teman sejawat membuat instrumen. Pada tahap menyusun rancangan diupayakan ada kesepakatan antara guru dan sejawat. Rancangan dilakukan bersama antara peneliti yang akan melakukan tindakan dengan guru lain yang akan mengamati proses jalannya tindakan. Hal tersebut untuk mengurangi unsur subjektivitas pengamat serta mutu kecermatan pengamatan yang dilakukan. Kedua, tahap pelaksanaan tindakan dilakukan dengan pembelajaran di kelas. Pada tahap ini guru peneliti giat melakukan tindakan menggunakan metode Card Sort berbantuan alat peraga. Rancangan tindakan tersebut sebelumnya telah dilatih untuk dapat diterapkan di dalam kelas sesuai dengan skenarionya. Skenario dari tindakan diupayakan dilaksanakan dengan baik dan wajar. Ketiga, tahap ini sebenarnya berjalan bersamaan dengan saat pelaksanaan. Pengamatan dilakukan pada waktu tindakan sedang berjalan, jadi, keduanya berlangsung dalam waktu yang sama. Pada tahap ini, guru yang bertindak sebagai peneliti 
melakukan pengamatan dan mencatat semua hal yang diperlukan dan terjadi selama pelaksanaan tindakan berlangsung. Pengumpulan data ini dilakukan dengan menggunakan tes prestasi belajar yang telah tersusun, termasuk juga pengamatan secara cermat pelaksanaan skenario tindakan dari waktu ke waktu serta dampaknya terhadap proses dan hasil belajar anak. dan keempat, tahapan ini dimaksudkan untuk mengkaji secara menyeluruh tindakan yang telah dilakukan, berdasarkan data yang telah terkumpul, kemudian dilakukan evaluasi guna menyempurnakan tindakan berikutnya. Refleksi dalam PTK mencakup analisis, sintesis, dan penilaian terhadap hasil pengamatan atas tindakan yang dilakukan. Jika terdapat masalah dari proses refleksi maka dilakukan proses pengkajian ulang melalui siklus berikutnya.

Pengumpulan data dalam penelitian ini menggunakan tes prestasi belajar. Tes prestasi belajar berupa tes soal isian maupun essay. Untuk menganalisis data hasil penelitian ini digunakan metode deskriptif. Untuk data kuantitatif dianalisis dengan mencari mean, median, modus, membuat interval kelas dan melakukan penyajian dalam bentuk tabel dan grafik. Indikator keberhasilan penelitian yang diusulkan dalam penelitian ini pada siklus I dan II mencapai nilai rata-rata 75,00 dengan ketuntasan belajar 85\%. dengan KKM yang ditetapkan untuk mata pelarajan IPA pada SD Negeri 1 Ubud adalah 65.

\section{Results and Discussion}

Penerapan Model Pembelajaran Children Learning In Science (CLiS) pada siklus I didapatkan hasil bahwa: rata-rata nilai 64,86 dari jumlah nilai secara klasikal 2400 dari seluruh siswa di kelas III A dan prosentase ketuntasan belajarnya adalah 72,97\%, yang tidak tuntas adalah 27,02\%. Hasil ini belum maksimal, karena belum mecapai indikator keberhasilan penelitian yang mencanangkan dengan minimal prosentase ketuntasan belajar $85 \%$. Dengan tindakan yang sangat maksimal dan pelaksanaan yang betul-betul mengikuti kebenaran teori sesuai dengan Model Pembelajaran Children Learning in Science (CLiS) dalam pembelajaran IPA di kelas III A SD Negeri 1 Ubud, dimana hasil yang diperoleh pada siklus II ini ternyata hasil belajar IPA meningkat secara signifikan dengan nilai ratarata 76,08, dan ketuntasan belajarnya adalah 94,59\%. Dari keseluruhan jumlah siswa, yaitu 37 hanya 35 siswa yanga bisa melampaui atau setara nilai KKM yaitu 65. Gambaran dari hasil penelitian ini dapat digambarkan pada histogram pada gambar 2.

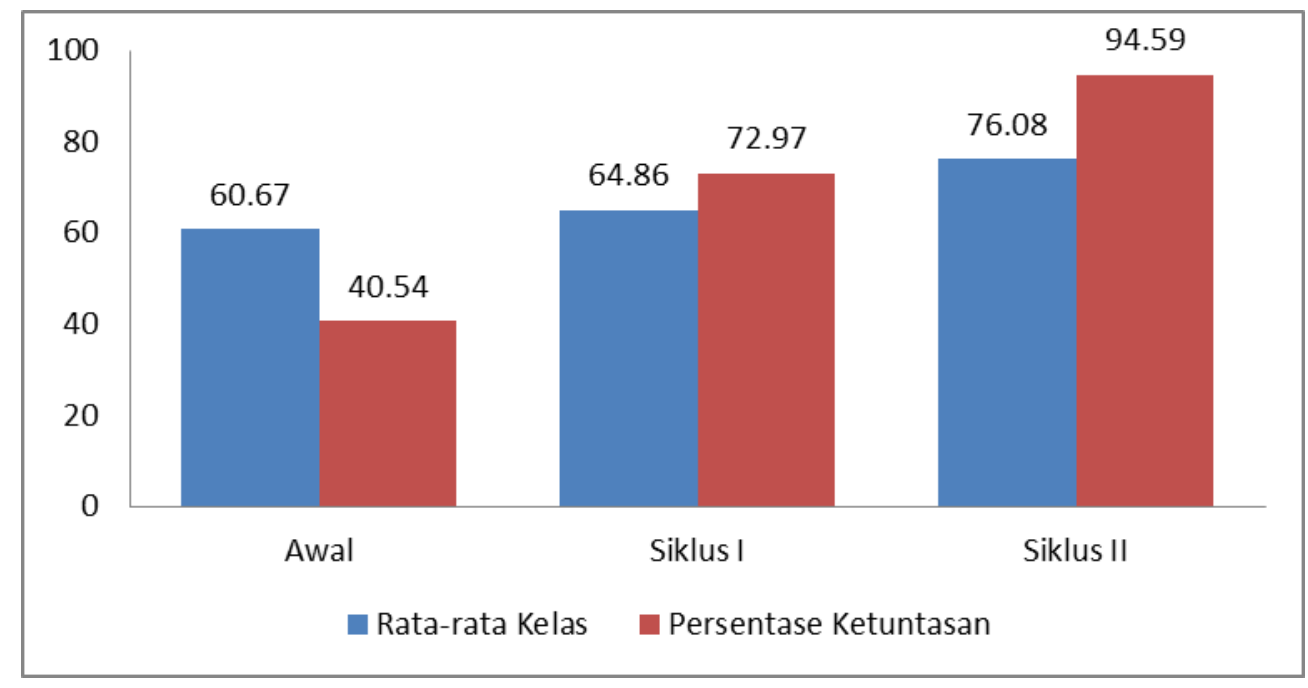

Gambar 2. Hasil Penelitian

Berdasarkan hasil penelitian dapat dilakukan dapat dinyatakan bahwa model CLiS berdampak positif terhadap prestasi belajar. Model pembelajaran Children Learning in 
Science (CLiS) adalah kerangka berpikir untuk menciptakan lingkungan yang memungkinkan terjadinya kegiatan belajar mengajar yang melibatkan siswa dalam kegiatan pengamatan dan percobaan dengan menggunakan LKS (Ismail, 2018). Rahayu dalam Arisantiani et al.,(2017); Rate Rusmala Sari, Indrawati, (2015) menyatakan bahwa model CLiS adalah salah satu model yang mengembangkan ide siswa dalam memecahkan masalah dalam proses percobaan. Model pembelajaran CLiS ini bertujuan untuk membentuk pengetahuan (konsep) ke dalam ingatan siswa agar konsep tersebut dapat bertahan lama, karena model pembelajaran CLiS memuat sederetan tahap-tahap kegiatan siswa dalam mempelajari konsep yang diajarkan. Dengan adanya model ini siswa akan lebih aktif karena sintak model pembelajaran ini lebih menekankan terhadap bagaimana cara siswa memecahkan masalah yang diberikan melalui pembelajaran. Keaktifan siswa dalam proses pembelajaran akan berdampak terhadap hasil belajar siswa tersebut. Pernyataan ini didukung oleh (Febrianto, 2016; Suarni, 2017; Zaeni \& Hidayah, 2002) yang menyatakan bahwa peningkatan keaktifan siswa berdampak juga terhadap peningkatan hasil belajar.

Model pembelajaran CLiS berdampak positif terhadap proses pembelajaran karena proses pembelajaranya berpusat pada siswa, siswa diberikan kesempatan untuk mempelajari, memberikan Ide atau gagasan untuk menyelesaikan masalah yang diberikan. Siswa merasa lebih dihargai dan tentunya hal ini menciptakan rasa percaya diri siswa. kepercayaan diri dapat diartikan sebagai sikap positif seorang individu yang memampukan dirinya untuk mengembangkan penilaian positif terhadap diri sendiri maupun terhadap lingkungan/situasi yang dihadapinya (Relita \& Regina, 2015). Berkembangnya rasa percaya diri sangat dipengaruhi dengan bagaimana seoarang pendidik menghargai siswanya. Dengan memberikan kesempatan kepada siswa untuk menyampaikan ide-Ide adalah salah satu yang bisa dilakukan. Pernyataan ini sesuai dengan pendapat dari Putri, (2018);(Yogica \& Selaras, 2002) Rasa percaya diri akan timbul apabila ada pemenuhan kebutuhan dihargai dan menghargai, karena dengan hal tersebut akan menimbulkan kekuatan, kemampuan, dan perasaan yang berguna bagi orang lain. Berdasarkan jabaran tersebut dapat dikatakan bahwa dengan adanya rasa keyakinan pada diri, akan membuat hasil belajar siswa meningkat. Pernyataan ini sesuai dengan pendapat dari Adriani, (2018);(Aisyah et al., 2019) rasa percaya diri siswa akan menjadi salah satu faktor pendorong meningkatnya hasil belajar siswa.

Selain temuan yang sudah dibahas sebelumnya dengan adanya model CLiS suasana belajar yang diciptakan kondusif yang memberikan kesempatan kepada siswa untuk mengembangkan pengetahuannya seluas-luasnya. Karena semua siswa diberikan kesempatan untuk menyampaikan ide-ide, serta siswa diberikan kesempatan untuk menguji apa yang mereka gagas sendiri. Dengan kesempatan ini siswa akan lebih merasa nyaman dan tentunya ini akan berdampak terhadap kemampuan berpikir kritis. Yang mana siswa tidak akan menerima begitu saja apa yang sampaikan oleh teman atau guru tanpa menganalisis dan mengevaluasi. Kemampuan berpikir kritis adalah kemampuan berpikir reflektif dan beralasan dalam mengambil keputusan (Dwijananti \& Yulianti, 2010; Nuryanti et al., 2018; Qomariyah, 2016; Rosy \& Pahlevi, 2015). Jadi, dengan adanya kesempatan untuk melakukan percobaan siswa akan mengembangkan kemampuan berpikir kritisnya. Dengan perkembangan berpikir kritis siswa mampu membangun pengetahuannya sendiri dengan baik, secara tidak langsung ini akan berdampak terhadap hasil belajar.

Penelitian yang dilakukan oleh Pratama, (2017) yang menyatakan bahwa terdapat pengaruh penggunaan model pembelajaran IPA dengan tipe CLiS meningkat terhadap hasil belajar. Ini dapat dilihat dari hasil penelitian yang dilakukan Nilai sig menyatakan $<0,01$, dan hasil pengujian dengan uji t posttest kelompok eksperimen dan kontrol -1,729 dan sig 0,097 nilai sig > 0, 01. Kusuma Wardani et al., (2017) menyatakan bahwa hasil penelitian menunjukkan nilai thitung lebih besar dari $\mathrm{t}_{\text {tabel }}=2,340>1,68385$ sehingga $\mathrm{H}_{0}$ ditolak dan $\mathrm{H}_{1}$ diterima dan nilai rata-rata posttest kelas eksperimen 82,36 lebih besar dari kelas kontrol 
74,20. Dapat disimpulkan bahwa ada efektivitas model pembelajaran CLiS perbantuan media slide PowerPoint terhadap hasil belajar IPA siswa kelas V SDN Pulerejo Kecamatan Pilangkenceng Kabupaten Madiun Tahun Pelajaran 2016/2017. Ismail (2018) menyatakan bahwa keterampilan proses sains setelah diterapkan model pembelajaran Children Learning in Science (CLiS) perbantuan multimedia meningkat secara signifikan dilihat dari nilai gainnya. Berdasarkan hasil analisis data diperoleh rata-rata $\mathrm{N}$-gain keterampilan proses sains 57\% untuk kelas eksperimen dan 49\% untuk kelas kontrol, Dapat disimpulkan bahwa model pembelajaran Children Learning in Science (CLiS) perbantuan multimedia dapat lebih meningkatkan keterampilan proses sains di bandingkan dengan pembelajaran konvensional perbantuan multimedia. Jadi, dapat dikatakan bahwa model CLiS berdampak positif terhadap hasil belajar.

\section{Conclusion}

Setelah dilakukan penggantian metode pembelajaran dari model pembelajaran yang konvensional menjadi model pembelajaran yang constructivism yaitu Model Pembelajaran Children Learning in Science (CLiS) ternyata hasil yang diperoleh meningkat dari data awal rata-rata 60,67 menjadi 64,86 pada siklus I. Setelah perlakuan tindakan dilakukan dengan cukup intents maka hasil yang diperoleh pada siklus II naik menjadi 76,08 dan mencapai ratarata sesuai kriteria ketuntasan minimal yang diharapkan. Berdasarkan pemaparan di atas, dapat disimpulkan bahwa: Penerapan Model Pembelajaran Children Learning in Science (CLiS) Secara Efektif Dapat Meningkatkan Prestasi Belajar IPA Siswa Kelas III A SD Negeri 1 UBUD Semester II Tahun Pelajaran 2018/2019.

\section{References}

Adriani, D. (2018). Pengaruh Percaya Diri, Kebiasaan Belajar dan Motivasi Belajar Terhadap Hasil Belajar Siswa Pada Mata Pelajaran Ekonomi. Jurnal Pendidikan Ekonomi, Manajemen Dan Keuangan, 2(1), 19-28. https://doi.org/http://dx.doi.org/10.26740/jpeka.v2n1.p19-28.

Arikunto, S. (2015). Dasar-Dasar Evaluasi Pendidikan. Bumi Aksara.

Arisantiani, N. K., Putra, M., \& Ganing, N. N. (2017). Pengaruh Model Pembelajaran Childrens Learning in Science (CLiS) Berbantuan Media Lingkungan Terhadap Kompetensi Pengetahuan Ipa. Journal of Education Technology, 1(2), 124. https://doi.org/10.23887/jet.v1i2.11774.

Asiyah, A., Walid, A., \& Kusumah, R. G. T. (2019). Pengaruh Rasa Percaya Diri Terhadap Motivasi Berprestasi Siswa pada Mata Pelajaran IPA. Scholaria: Jurnal Pendidikan Dan Kebudayaan, 9(3), 217-226. https://doi.org/10.24246/j.js.2019.v9.i3.p217-226.

Dwijananti, P., \& Yulianti, D. (2010). Pengembangan Kemampuan Berpikir Kritis Mahasiswa Melalui Pembelajaran Problem Based Instruction Pada Mata Kuliah Fisika Lingkungan. Jurnal Pendidikan Fisika Indonesia, 6(2), 108-114. https://doi.org/10.15294/jpfi.v6i2.1122.

Febrianto, E. (2016). Upaya Peningkatan Keaktifan dan Hasil Belajar Melalui Model Pembelajaran Think Pair Share (TPS) Berbantuan Media Power Point pada Mata Pelajaran Pengantar Ekonomi dan Bisnis Siswa SMK Negeri I Banyudono Tahun Ajaran 2015/2016. Media Konservasi, 2(1), $11-40$. http://dx.doi.org/10.1016/j.ecoenv.2017.03.002\%0Ahttp://www.fordamof.org/files/Sistem_Agroforestri_di_Kawasan_Karst_Kabupaten_Gunungkudul_Untu k_Pengelolaan_Telaga_Sebagai_Sumber_Air_Berkelanjutan.pdf\%0Ahttps://extension. msstate.edu/sites/default/files/pu. 
Ismail, A. (2018). Penerapan Model Pembelajaran Children Learning in Science (CLiS) Berbantuan Multimedia Untuk Meningkatkan Penguasaan Konsep Fisika Siswa Sma. Jurnal Petik, 1(1), 19. https://doi.org/10.31980/jpetik.v1i1.55.

Kusuma Wardani, R. F. A., Rifai, M., \& Mandalwati, T. K. (2017). Efektivitas Model Pembelajaran CLiS Berbantuan Media Slide Powerpoint Terhadap Hasil Belajar IPA. Premiere Educandum: Jurnal Pendidikan Dasar Dan Pembelajaran, 7(02), 104. https://doi.org/10.25273/pe.v7i2.1596.

Nuryanti, L., Zubaidah, S., \& Diantoro, M. (2018). Analisis Kemampuan Berpikir Kritis Siswa SMP. Jurnal Pendidikan: Teori, Penelitian, Dan Pengembangan, 3(2), 155-158. https://doi.org/10.17977/JPTPP.V3I2.10490.

Panjaitan, S. (2017). Meningkatkan Hasil Belajar Ipa Melalui Media Gambar Pada Siswa Kelas Iia Sdn 78 Pekanbaru. Primary: Jurnal Pendidikan Guru Sekolah Dasar, 6(1), 252. https://doi.org/10.33578/jpfkip.v6i1.4105.

Pratama, I. (2017). Pengaruh Model CLIS Terhadap Hasil Belajar Siswa Kelas V The Effect Of Learning Model CLiS Toward Student Learning. MIMBAR PGSD Undiksha, 1(1), 324-342. https://doi.org/http://dx.doi.org/10.23887/jjpgsd.v1i1.818.

Putri, E. S. (2018). Pengaruh Kepercayaan Diri Terhadap Prestasi Belajar Siswa pada Mata Pelajaran Sejarah Kelas X Program IPA di Sma Negeri 1 Cerme Gresik. AVATARA, eJournal Pendidikan Sejarah, 6(3), 79-87.

Qomariyah, E. N. (2016). Pengaruh Problem Based Learning terhadap Kemampuan Berpikir Kritis IPS. Jurnal Pendidikan Dan Pembelajaran, 23(2), 132-141.

Rate Rusmala Sari, Indrawati, A. A. G. (2015). Model Pembelajaran CLIS (children learning in science) dengan Orientasi Melalui Observasi Gejala Fisis dalam Pembelajaran IPAFisika DI SMP. Jurnal Pendidikan Fisika, 3(4), 324-329. https://jurnal.unej.ac.id/index.php/JPF/article/view/1427.

Relita, D. T., \& Regina, F. (2015). Hubungan antara Rasa Percaya Diri dengan Hasil Belajar Siswa Kelas Xi Sekolah Menengah Atas Karyasekadautahun Pelajaran 2014 / 2015. Jurnal Profit, 2(2), 122-130.

Rosy, B., \& Pahlevi, T. (2015). Penerapan Problem Based Learning untuk Meningkatkan Kemampuan Berpikir Kritis dan Keterampilan Memecahkan Masalah. Prosiding Seminar Nasional, 160-175.

Suarni. (2017). Melalui Pendekatan Pembelajaran Pakem Untuk Kelas Iv Sd Negeri 064988 Medan Johor. Journal of Physics and Science Learning, 01(2), 129-140. https://jurnal.uisu.ac.id/index.php/PASCAL/article/view/347.

Yanti, N. L. M. S. M. (2017). Pengaruh Model Pembelajaran Creative Problem Solving Berbasis Educative Games Terhadap Kemampuan Berpikir Kritis dan Hasil Belajar Ipa Kelas IV Di Gugus IV Kecamatan Kuta, Kabupaten Badung. Jurnal Ilmiah Pendidikan Dan Pembelajaran, 1(2), 90-99. https://doi.org/10.23887/JIPP.V1I2.11967.

Yogica, R., \& Selaras, G. H. (2002). Pengaruh Model Pembelajaran Kooperatif Tipe Course Review Horay Bermuatan Literasi Sains terhadap Kompetensi Belajar Peserta Didik Pada Materi Sistem Reproduksi Manusia di SMAN 4 Pariaman The Influence of the 
Cooperative Learning Model Course Review Horay. 35-44.

Zaeni, J. A., \& Hidayah, F. F. (2002). Analisis keaktifan siswa melalui penerapan model teams game tournamants (TGT) pada materi termokimia kelas XI IPA 5 di SMA 15 Semarang. Seminar Nasional Pendidikan, Sains Dan Teknologi Fakultas Matematika Dan Ilmu Pengetahuan Alam Universitas Muhammadiyah Semarang, 8, 416-425. https://jurnal.unimus.ac.id/index.php/psn120120/article/view/3086. 